\title{
Improving Positive Learner Motivation towards Islamic Studies
}

\section{Alan Mohammed Saeed Mustafa}

\author{
Duhok, Kurdistan
}

\begin{abstract}
The success in Islamic studies is getting lower and lower, and many learners are having difficulties with learning Islamic studies and with that also the motivation for learning Islamic studies decreases. The difficulties are shown in both, mastering the material in school and solving the exercises at home. For this reason, the study aims to improve positive learner motivation in learning Islamic studies. The aim of this study is to examine student's motivation towards learning Islamic studies. The purposes of methodology are to explain research methodology, clarify the procedures that used in this research, define the measurements used in planning the instrument, explain data collection, and to provide a clear clarification of the statistical method used in order to analyse data. A quantitative method used in order to analyse data gathered by the researcher. The researcher used a questionnaire to obtain data about the learners' motivation and analyse them. 89 students from different universities in Duhok participated in this study. Multiple regression analysis used in this study, as seen in table (3), the coefficients analysis shows the B value for social factor $=.611>0.01$, which supported the first research hypothesis, the $B$ value for capabilities factor $=.712>0.01$, which supported the second research hypothesis and the $B$ value for behavior factor $=.609>0.01$, which supported the third research hypothesis.
\end{abstract}

Keywords - Islamic studies learning, Motivation, Duhok, Kurdistan.

\section{INTRODUCTION}

The importance of learners' motivation is reflected in the vast amount of related research in the teaching and learning process (Abudhahir, et, al. 2018). Academics, mostly in the Educational Psychology domain, examine the role of motivation in the learning and teaching context in an attempt to understand why some learners seem to learn and succeed in school contexts, while other learners seem to struggle to obtain analogous outcomes (Yunus, et, al. 2018). In this respect, a considerable body of research highlights not only the various cognitive, motivational, and regulatory constructs, but also the importance of the social context and the interactions with other constructs in the development of learners' motivation (Arar \& Haj-Yehia, 2018). However, most of these studies were focused on middle school and college learners.

What can instructors do to improve learners' motivation in learning especially in the classroom of Islamic studies? Regarding that question, the connection between learners' motivation and their achievement in learning has become a common discussion. Almost all education experts and education stakeholders agree on the role of motivation influence learners' behavior in learning process. In the literature states that to understand learners' behavior we need to know their motives (Alias, et, al. 2013). Whereas, as an educator, the author thinks that the process is not only to know what aspect motivate learners in learning but also try to help them in developing their motivation and trigger it to become a positive circumstance in learning process.

This can be a key point that directs the learners to a better conceptual change. The conceptual change here refers to the enrichment and or revision of the prior knowledge which learners already have (Yusoff, et, al. 2018). Fatima, et, al. (2017) has addressed in her paper about cognitive conflict, the use of analogies and cooperative and shared learning as three kinds of instructional strategies which can be used to encourage the conceptual changes. Meanwhile, the author argues that motivation profiles also play a significant role on supporting of conceptual change process. As an effect of the previous opinion, the questions in the beginning of this essay should be an important issue to be discussed among the educational practices.

Accordingly, the importance of learner motivation is reflected in the realm of Islamic studies education which treats motivation as a desirable outcome and a means to enhance understanding. Researches in the field support not only the close association between cognitive, motivational, and affective factors in learners' teaching (Shahbaz, et, al. 
2017), but also the importance of the specific classroom context and the learners' learning context in the formation of learners' affect. Yet, further research is needed on how these constructs interact and relate with each other (Huda, et, al. 2015). In this respect, the main objective of the present study was to investigate the relationships among elementary learners' affective constructs, their achievement goals, and their behavior. The study was conducted in a specific context and learners' performance was measured based on an explicitly designed test.

In the context of self-regulated learning, research (Munir \& Hartono, 2016) revealed that learner motivational beliefs and regulatory actions differed across academic domains (e.g. Islamic studies, science). Many theorists contended that self-regulated learning can be taught across contexts and situations (Aziz, et, al. 2016). With the shift of educational paradigm from efficiency- to ability-driven, learners' education is tailored according to their learning needs, and schools are given autonomy to develop curriculum and pedagogies (Ahmad, et, al. 2014). Such autonomy is viewed as a harmonious yet political process to mediate the expectations of various key stakeholders in the Singapore's educational system (Huda \& Kartanegara, 2015). Despite the combined efforts of researchers, instructors, and stakeholders to promote motivation in learners, there is still a research gap in the evaluation of self-regulated learning for Islamic studies and science in the Singaporean context, in particularly the secondary schools. The author believes that using an appropriate context engages learner to be active in the classroom of Islamic studies. Thelearners 'activity is one basic behavior which can make the learning process in the classroom become more meaningful not only as a one way direction fromthe instructors. In this point, learners seen not as an empty vessel that should be fill in with theknowledge from the instructors but as the actor of the process, teacher only taking account ingiving support. However, learners' behavior in learning process is multi-determined. And thevarious reasons can influence study behavior, for instance a spontaneous interest in the learning material, get a higher score because of a desire to prove oneself, external expectations, or futureprofessional goals (Van Praag, et, al. 2016). In addition,Al-Jubari, et, al. (2017) state that one of the factors which affect learners' attitude towards science is the good quality of teaching process which stimulates interest andengagement. Therefore, this essay will give explanation about motivation and the use of anadequate context to improve learners' motivation in learning Islamic studies.

\section{THE CONCEPT OF MOTIVATION}

First and foremost, we have to know what motivation is. In a simple definition,motivation is reasons individuals have for behaving in a given manner in a given situation (Purwana, et, al. 2015). In a more complex definition, "motivation is defined as a potential to direct behavior that is built into the system that controls emotion. This potential may be manifested in cognition, emotion and/ or behavior" (Gilavand, et, al. 2015). The manifestations relate with what will happen and what will learners get after they pursue in a learning process. Moreover, the author is in line with an opinion which states goals and needs of a learning process will represent by the emotion, attitudes and values of the learners (Wahyu, et, al. 2017). Because of that instructors should taking account in promoting and facilitating the increasing of learner's attitudes and manners. And, a classroom of Islamic studies has to be supporting environment to this issue with providing autonomy, competence development and the social belonging. Meanwhile, to make a limitation, in this essay the author will only explain on how to build a support to the learning environment for learners which lead to developing their autonomy, competence and social belonging.

In Educational Psychology, motivational theories seek to investigate what gets individuals to move towards what activities and to describe the characteristics of these activities (Shirin, et, al. 201). Motivation is characterized as a complex and multidimensional construct (Islam, 2014). Abudhahir, et, al. (201) refers to five frameworks of socialcognitive constructs that have recently been used in research on learners' motivation in the classroom context. The framework of self-beliefs (e.g. self-efficacy) asserts that when learners believe that they can do well in the educational settings, they feel confident, tend to try hard, persist more, and perform better (Yunus, et, al. 2018). Attribution and control beliefs (Arar \& Haj-Yehia, 2018) support that learners who believe that they have more personal control of their learning are expected to do better and achieve at higher levels than learners who do not feel in control of their learning behavior. Interest and intrinsic motivation is another theoretical framework that expands the traditional distinction between learners' intrinsic and extrinsic motivation to a more complex differentiation of extrinsic motivation. These different types of interest were found to lead learners to different learning outcomes (Alias, et, al. 2013). Self-efficacy plays an important role in improving problem-solving skills of middle school learners (Yusoff, et, al. 2018) and science achievement in high schools. For instance, self-efficacy had direct influence on 
Islamic studies achievement of gifted high school learners (Fatima, et, al. 2017), and was a significant predictor of chemistry achievement in college learners (Shahbaz, et, al. 2017). Learners with highly perceived self-efficacy in Islamic studies were more likely to use higher-order cognitive and metacognitive strategies (Huda, et, al. 2015). Likewise, science has an emphasis on the importance of inquiry skills where learners discover, produce, and evaluate scientific knowledge. Coupled with scientific thinking and reasoning skills, learners are encouraged to experience the knowledge construction process. Inquiry learning should be structured such that learner learning is facilitated to plan and conduct own investigation (Munir \& Hartono, 2016). In this approach, learners are likely strategic and engaged in learning contexts such as Islamic studies and science.To begin with, many experts have argued their opinions and studies about motivation. Aziz, et, al. (2016) say that "To be motivated means to be moved to do something". Ahmad, et, al. (2014) indicates that success in Is lamic studies is a powerful influence on the motivation to achieve. The study suggests that the decline in positive attitudes toward Islamic studies can be explained in part as functions of lack of teacher supportiveness and classroom environment. To facilitate learners' motivation,rationales need to produce two effects: learners need to see the importance and personal utility within the task, and learners need to perceive high autonomy while working on that task. Besides, it is also stated in literature that learners' belief in Islamic studies can be affected by their beliefs in the following aspects: the nature of Islamic studies, the way of teaching and learning and their beliefs in instructors. In addition, learners' perception of success in learning Islamic studies is highly related to their motivational attitudes. Instructors' actions, attitudes and instructional design quality for Islamic studies lessons have greatly influenced learners' motivation. Discussing about motivation in education, we may also refer to a theory of self-determination which is commonly called self-determination theory. This theory argues the important of competence, relatedness and autonomy to understand the content and the process of goal chasing (Huda \& Kartanegara, 2015).

Van Praag, et, al. (2016) state in their paper that in motivation theory, the higher levels of motivations do not directly mean a high outcome, since the quality of the motivation is poor. In addition, they explain about two kinds of motivation those are autonomous which the motives come up from the person itself internally and controlled motivation which the motives are influenced and regulated by the external factors. They present a research consists of two studies to address and to compare about four motivational profiles: a good quality motivation, a high quantity motivation, a low quantity motivation and a poor quality motivation. These groupings based on the existence the autonomous and the controlled motivations in each cluster. The result of these study shows that "learners in the good quality motivation group displayed the most optimal pattern of educational outcomes relative to all other group of learners in the research. The good quality motivation means the high of autonomous motivation and the low of controlled motivation. The author's opinion in the present paper is in line with the implication of the result from the study that instructors should provide a good quality motivation in the classroom of Islamic studies. And, the author proposes the use of constructivism theory as a base for instructors in creating a learning environment that can facilitate the complacency of learners' need of autonomy, competence and relatedness. Constructivist argues that "the view of learning is the importance of connecting the new knowledge to be acquired with the existing knowledge that learners have, in order to promote meaningful learning(Al-Jubari, et, al. 2017). From this view, we can say that learners actively construct a new knowledge by using their prior knowledge. And if the construction process is "interesting" then the learners' motivation will be increase. However, the problems are what the "interesting" mean and how instructors can make the learners move from their prior knowledge into a new knowledge interestingly? Let learner do the Islamic studies and allow them to feel a reinvent the concept of Islamic studies in the classroom might be one of the interesting way to engage learners and increase their motivation toward the learning activity. To make it happen, instructors can use a "context" as a starting point in the learning process. Meanwhile, it is well-known that talking about context is not as simple as we think. Furthermore, there are two points of view to define what context exactly is. First, context is seen as a learning environment where the learning takes place. Second, a characteristic of a task presented to the learners (Purwana, et, al. 2015). Regarding those two types of context, the author point out that instructors have to create a teaching and learning environment by choosing an appropriate context which can build learners' positives emotions toward the lessons. Consequently, the positive emotion will increase learners' attention and effort to do their best in the learning process.

In addition, according to Gilav and, et, al. (2015) a good context is a context which can engage learners to problem 
solving and problem posing. They see teaching and learning not in a separate way, they state that these teaching and learning are collaborated one another by the instructors as a development process. And in the development process the instructors give chance to learners to be young and give trust to them that they can do it. In this view, instead of just transferring the knowledge, instructors support the learners. In this view, Islamic studies are seen as human activity. In Islamic studies empathizing learners organize information into chart and tables, noticing and exploring pattern, putting forth and conjectures, and trying to convince one another of their thinking. And in the Islamic studies empathizing there are three main points that should be considered by the instructors, those are big ideas, strategies and models .

In the following, the author will give a brief explanation about big ideas, strategies, models and their correlation one another based on the point of view from Wahyu, et, al. (2017). First, big ideas related to the structure of Is lamic studies. These ideas are big since they are fundamental to Islamic studies, and these make a big leap to the development of learners' cognitive. Learners need a hard effort to gain these big ideas in their proficiency. In other words, the big ideas are important steps that lead to new knowledge and learners need them to understand the concept of Islamic studies and use it in the problem solving or face with the Is lamicconcepts. Second, strategies are seen as the schemes that use by the learners in their process to reach the big ideas. Strategies represent the way of learners thinking on solving a problem or deal with the given activity in the learning Islamic studies. Then the third, models are the tools that are used by the learners to thought (Shirin, et, al. 2017). We used models to represents the informal solutions into a more formal generable solution. In other words, we develop models of thinking into models for thinking. However, the shift from models of thinking into models for thinking is not easy for learners. Islam,(2015) argues about what instructors should do when learners do not come up with a model to solve a problem. First the instructors should give support to the learners that lead learners to develop their Islamic studies thinking and represents the problem as model of and moves to model for. Moreover, instructors need to see the world through the eyes of the learners so that she/he can predict or might follow the way of learners' thinking. In this case, teacher has to stand in an author's point of view where the actor here is the learners. Furthermore, when the learners still cannot come up to model their ideas, teacher might explores what learners already have and guide them for instance by using further questions and giving hints until they recognize the idea. In a learning framework, models, strategies and big ideas are dynamic. They are interplay each other in the activity. By then, the context play role as a base to support the emergence of models, strategies and big ideas. This is why instructors should provide a context that real in learners' mind and can attract learners to reveal their way of thinking. From a context, learners try to model it in a simple representation, then move on to model for thinking and finally using the strategies to reach the big ideas. The author believes that if the context used by instructors is interesting then the learners' motivation to join in the learning activity will be increase. Let me try to illustrate the use of context and its relation with models, strategies and big ideas in the following example. If instructors want learners understand about a concept of place value then instead of just give the definition and concept directly to the learners, instructors engage learners in a learning activity. Instructors use the context of inventory and counting the stuff in the class. Ask learners to work in a small group, then support them to model the situation, perhaps some learners will use quantity of tallies, model with symbols, model Group, or an open number line. Some strategies will appear, such as counting one by one, grouping by 5 or 10 , skip counting etc. Then instructors facilitate a class discussion and lead the learners to understand the concept of place value together. From the given example above, we can see that instructors give opportunity to the learners to act and feel the sense of doing Islamic studies. Since the activity based on something that real in their mind and they can deal with it, the learners will easy to give their attention to participate in the activity. Instructors also provide chance for the various strategies that might appear. So the strategies are not something given or transfer by the instructors but come up from learners' minds. With classroom settings becoming a focus of cognitive-motivational research, there is a need to examine the processes of self-regulation and motivation in the context of learning. The context of learning includes social and cultural elements as well as educational or instructional factors (Purwana, et, al. 2015). Research findings showed that social-contextual relations have significant impact on learners' motivation, self-regulation, and achievement in middle and high schools. Autonomy support refers to identifying and fostering learners' intrinsic motivation by giving them choices or opportunities; fostering understanding and interest with respect to learning; providing rationales and informational feedback; as well as encouraging self-regulated learning. From the self-determination theory perspective, teacher autonomy support promotes a sense of volitional learning whereby 
learners are allowed to act upon their personal interests. As such, perception of teacher autonomy support is measured by the Learning Climate Questionnaire.

In a more specific way, to teach Islamic studies in context, Huda \& Kartanegara, (2015) explains five strategies which can be used by the instructors. They are relating, experiencing, applying, cooperating, and transferring. Those strategies are known as contextual teaching strategies. The following explanations about the contextual teaching strategies are based on Crawford's opinion. The first, relating is used by instructors if they want to introduce anew concept which is completely familiar to learners or connects to what learners already know. The second is experiencing, in this strategy, learners do some exploration, discovery and invention process to understand a new concept. The third is applying, in this strategy in understanding a concept learners are supported to apply it in the problem solving. Fourthly is cooperating. In this strategy the main point is to share the idea, discuss it and communicate itwith the fellow learners, facilitated by the instructors, in order to make them understand the notionabout the concept. The last is transferring which means using knowledge in a new context ornovel situation.

\section{MOTIVATION OF LEARNING ISLAMIC STUDIES}

The importance of motivation in Islamic studies has been well documented (Munir \& Hartono, 2016). Chai, et al (2016) perceives motivation not as another dimension of affect but as another perspective that illuminates some aspects of affect. He considers motivation as a potential to direct behavior that is built into the system which controls emotion. He states that motivation can be indirectly observed through cognition, emotion, and behavior. In this respect, a learner's desire to get involved in an Islamic studies task may be driven by his belief about the importance of the task (cognition), his anger for the failure to solve the task (emotion), or his persistence to solve the task (behavior). Aziz, et, al. (2016), suggests the integration of motivation into theories of self-regulation established on needs and goals. Particularly, he views motivation in terms of needs and goals, considering needs as more general than goals influenced by learners' beliefs of themselves, as learners of Islamic studies. In line with Elliot's model (1999), Ahmad, et, al. (2014) has found that different dominating needs lead to the adoption of different primary goals and therefore to different behavior in Islamic studies situations. Huda \& Kartanegara, (2015), in line with socialcognitive theories incorporated the issues of motivation in the socio-constructivist perspective on learning, recognizing the close association between (meta) cognitive, motivational, and affective factors in learners' learning. Particularly, they consider learners' learning as a form of engagement that allows them to actualize their identity through the involvement in activities situated in a specific context. Accordingly, learners' identity reveals their needs, their values, and their beliefs which are expressed through their emotions. These affective constructs are related to the development of specific motivation. In line with the framework of social cognitive models, this theoretical perspective states that the specific classroom-context and learners' context is in close interaction with learners' affective constructs, learning, and problem solving.

\section{METHODOLOGY}

The aim of this study is to examine student's motivation of Islamic studies learning in the in Duhok. The purposes of methodology are to explain research methodology, clarify the procedures that used in this research, define the measurements used in planning the instrument, explain data collection, and to provide a clear clarification of the statistical method used in order to analyse data. A quantitative method used in order to analyse data gathered by the researcher. The researcher used a questionnaire to obtain data about the learners' motivation and analyse them. 89 students from different universities in Duhok participated in this study.

\section{RESULTS}

Table.1: Reliability analysis

\begin{tabular}{|l|l|l|}
\hline Factor & $\begin{array}{l}\text { Number of } \\
\text { questions }\end{array}$ & Cronbach Alpha \\
\hline Social & 10 & .725 \\
\hline Capabilities & 9 & .733 \\
\hline Behaviour & 10 & .744 \\
\hline
\end{tabular}

By the author from SPSS software

Table (1) shows the reliability result for three factors used to measure students motivation of learning Islamic studies, these factors are social factor, capabilities factor and behaviour factor. The result for social factor was .725 for ten questions, the result for capabilities factors was .733 for nine questions and the result for behaviour factor was .744 for ten question, the findings revealed that all factors used to measure students' motivation of learning Islamic studies are reliable. 
Table.2: Correlational analysis

\begin{tabular}{|c|c|c|}
\hline & & $\begin{array}{c}\text { Motivation of Islamic } \\
\text { studies learning }\end{array}$ \\
\hline \multirow{3}{*}{$\begin{array}{l}\text { Socia } \\
1\end{array}$} & Pears on Correlation & $.671^{* *}$ \\
\hline & Sig. (2-tailed) & .000 \\
\hline & $\mathrm{N}$ & 89 \\
\hline \multirow{3}{*}{$\begin{array}{l}\text { Capa } \\
\text { bilitie } \\
\text { s }\end{array}$} & Pears on Correlation & $.664^{* *}$ \\
\hline & Sig. (2-tailed) & .000 \\
\hline & $\mathrm{N}$ & 89 \\
\hline \multirow{3}{*}{$\begin{array}{l}\text { Beha } \\
\text { viour }\end{array}$} & Pears on Correlation & $0541^{* *}$ \\
\hline & Sig. (2-tailed) & .000 \\
\hline & $\mathrm{N}$ & 89 \\
\hline
\end{tabular}

In Table 2, the correlational analysis presents the values of the identified correlation tests. The strength of the relationship between variables is determined by the correlational analysis. According to the correlation test, the social factor has positive correlation $\left(r=674^{* *}, \mathrm{p}<0.01\right)$ with the motivation factor. The positive linear relationship between social and motivation is moderately strong. The capabilities factor has a positivecorrelation $\left(r=.664^{* *}\right.$, $\mathrm{p}<0.01)$ with the motivation factor. The positive linear relationship between capabilities and motivation factors is moderately strong. The behavioural factor has a positive correlation $\left(\mathrm{r}=.541^{* *}, \mathrm{p}<0.01\right)$ with the motivation. The positive linear relationship between the motivation and behavioural factors is moderately strong.

Table.3: multiple regression analysis

\begin{tabular}{|c|c|c|c|c|c|c|}
\hline \multicolumn{2}{|c|}{ Model } & \multicolumn{2}{|c|}{ Unstandardized coefficients } & \multirow{2}{*}{$\begin{array}{l}\text { Standardized coefficients } \\
\text { Beta }\end{array}$} & \multirow[t]{2}{*}{$\mathrm{t}$} & \multirow[t]{2}{*}{ Sig. } \\
\hline & & B & Std. error & & & \\
\hline \multirow[t]{4}{*}{1} & Constant & 0.12 & .014 & & .814 & .014 \\
\hline & Social & .611 & .001 & .601 & 26.541 & .000 \\
\hline & Capabilities & .712 & .012 & .703 & 28.546 & .000 \\
\hline & Behaviour & 609 & .019 & 601 & 27.453 & .000 \\
\hline
\end{tabular}

Multiple regression analysis used in this study, as seen in table (3), the coefficients analysis shows the B value for socialfactor $=$ $.611>0.01$, which supported the first research hypothesis, the B value for capabilities factor= .712>0.01, which supported the second research hypothesis and the $\mathrm{B}$ value for behavior factor $=.609>0.01$, which supported the third research hypothesis.

\section{CONCLUSION}

To sum up, learners' motivation related to their behaviors in the learning process is multi-determined. We might use the motivation point of view to get more insight about motivation in education terminology. Within SDT motivation is classified regarding to its quality and quantity and based on the study by Vansteenkiste et al. (2009) the good quality motivation-high autonomous and low controlled motivation-give a significant influence in improvement of learners' learning outcomes. Therefore, in the classroom of Islamic studies instructors need support the emergence of the autonomy of the learners. In fact, in supporting learners and improve their motivation towards science especially Is lamic studies, the author believes that there is a correlation between the roles of teacher and learners' motivation. If the teacher designs an adequate teaching and learning activity for the learning process, the learners' interest will increase. Thus, using a good context, which is selected by contextual teaching strategies, can be a good starting point in that Islamic studies classroom activities. The contextual teaching strategies which are proposed by Crawford (2001)consist of relating, experiencing, applying, cooperating, and transferring. Furthermore, the high motivation will lead to a more conducive situation for improving the learners' understanding to higher cognitive level. However, further studies are needed to flesh out this idea, for instance to explore more the technical aspect of choosing a good context to be used in a classroom. Multiple regression analysis used in this study, as seen in table (3), the coefficients analysis shows the B value for social factor $=$ .611>0.01, which supported the first research hypothesis, the $\mathrm{B}$ value for capabilities factor $=.712>0.01$, which supported the second research hypothesis and the $\mathrm{B}$ value for behavior factor $=.609>0.01$, which supported the third research hypothesis. 


\section{REFERENCES}

[1] Alias, N., Siraj, S., Daud, M. K. A. M., \& Hussin, Z. (2013). Effectiveness of Facebook based learning to enhance creativity among Islamic studies students by employing Isman instructional design model. Turkish Online Journal of Educational TechnologyTOJET, 12(1), 60-67.

[2] Abudhahir, R. A. S., \& Ali, A. M. (2018). English for Islamic Studies: Should I Learn English?-From the Eyes of Islamic Studies Students. LSP International Journal, 5(1), 1-12

[3] Yunus, A., Hamzah, M. I., Razak, K. A., \& Lubis, M. A. L. A. (2018). Students'perceptions On Parental Background And Their Academic Performance In Is lamic Studies In Nigeria. e-Bangi, 13(1), 22-25

[4] Arar, K., \& Haj-Yehia, K. (2018). Perceptions of educational leadership in medieval Islamic thought: a contribution to multicultural contexts. Journal of Educational Administration and History, 50(2), 69-81.

[5] Yusoff, W., Mazwati, W., Preece, A. S., \& Hamzah, L. M. (2018). Students' Experiences in Teaching and Learning Islamic Education Using Philosophical Inquiry Method. Journal of Education and Learning, 12(2), 266-274.

[6] Fatima, S., Mehfooz, M., \& Sharif, S. (2017). Role of Islamic religiosity in predicting academic motivation of university students. Psychology of Religion and Spirituality, 9(4), 377.

[7] Shahbaz, M., Islam, M., \& Malik, M. A. (2017). Role of Gender Differences and Parents' Education in Shaping L2 Motivation of Pakistani Students. Journal of Research \& Reflections in Education (JRRE), 11(2), $12-21$

[8] Arar, K., \& Haj-Yehia, K. (2018). Perceptions of educational leadership in medieval Islamic thought: a contribution to multicultural contexts. Journal of Educational Administration and History, 50(2), 69-81.

[9] Huda, M., Kartanegara, M., \& Zakaria, G. A. N. (2015). The Effect of Learning Strategy of Reading Aloud on Students' Achievement in the Subject of Islamic Studies at Secondary School in Semarang. International Journal of Education and Research, 3(2), 577-588.

[10] Munir, S., \& Hartono, R. (2016). Islamic magazine articles to enhance students' reading skill and build their character values. International Journal of Education, 9(1), 68-73.

[11] Aziz, A. A., Ibrahim, M. A., Shaker, M. H., \& Nor, A. M. (2016). Teaching Technique of Islamic Studies in
Higher Learning Institutions for Non-Arabic Speakers: Experience of Faculty of Quranic and Sunnah Studies and Tamhidi Centre, Universiti Sains Islam Malaysia. Universal Journal of Educational Research, 4(4), 755-760.

[12] Ahmad, I. S., Abdullah, H., \& Ghani, M. F. A. (2014). Attitudes and motivation toward learning the English Language among Students from Islamic Education System Background: Exploring the views of teachers.Journal of Education and Learning (EduLearn), 8(3), 195-208.

[13] Huda, M., \& Kartanegara, M. (2015). Islamic Spiritual Character Values of al-Zarnūjī’s Ta'līm alMuta'allim. Mediterranean Journal of Social Sciences, 6(4), 229.

[14] Van Praag, L., Agirdag, O., Stevens, P. A., \& Van Houtte, M. (2016). The perceived role of Islamic religiosity in minorities' educational success in Belgium. A cure or curse?. Social Compass, 63(4), 529-546.

[15] Al-Jubari, I., Hassan, A., \& Hashim, J. (2017). The role of autonomy as a predictor of entrepreneurial intention among university students in Yemen. International Journal of Entrepreneurship and Small Business, 30(3), 325-340.

[16] Purwana, D., Suhud, U., \& Arafat, M. Y. (2015). Taking/receiving and giving (TRG): A comparis on of two quantitative pilot studies on students' entrepreneurial motivation in Indonesia. International Journal of Research Studies in Management, 4(1), 314.

[17] Gilavand, A., Barekat, G., \& Hosseinpour, M. (2015). Evaluation of Dental Students' Motives and Viewpoints on their Career Choice in Ahvaz. Jentashapir Journal of Health Research, 6(6).

[18] Wahyu, K., Amin, S. M., \& Lukito, A. (2017). Motivation cards to support students' understanding on fraction division. International Journal on Emerging Mathematics Education, 1(1), 99-120.

[19] Shirin, H. B., Hassan, S. S. S., \& Islam, M. S. (2017). Interaction In E-Learning Environment: Does It Fulfill With Islamic Teaching?. MOJEM: Malaysian Online Journal of Educational Management, 2(4), 36-52.

[20] Islam, M. M. (2014). Factors influencing the academic performance of undergraduate students in Sultan Qaboos University in Oman. Journal of Emerging Trends in Educational Research and Policy Studies, 5(4), 396. 